\title{
Determinants of Length of Stay Tourists in Tanjung Puting National Park Central Kalimantan Province
}

\author{
Irawan, I Made Benjamin, Ngakan Putu Oka, Rahmatia Yunus \\ (Faculty of Economics, Univ. Palangkaraya, the Tunjung Nyaho Campus)
}

\begin{abstract}
Biodiversity of flora and fauna which are owned by in Central Kalimantan province as well as high and unique (Haryanto, 2009). Potential it provides opportunities for the development of nature tourism (ecotourism) has appeal for tourists to visit and stay longer in tourist area. The purpose of the study is to analyze and quantify the determinants factors of length of stay of tourists in the tourist area of Tanjung Puting National Park. Methods in this study is survey and observation, using a questionnaire to obtain information related to both variables exogeneous or endogenous. Research location is in Tanjung Puting National Park in West Kotawaringin administrative regions, Central Kalimantan Province and conducted in April-June 2012. The Population in this study were all tourists, both foreign tourists and domestic tourists who visited attractions Tanjung Puting National Park. Types and sources of data used in this study is primary and secondary data. The samples carried through non probability sampling techniques, namely Convenience sampling or sampling based on ease (Sugiono, 2002), and the sample size was 150 respondents. Analysis tool that uses statistical analysis of test models Path Analysis using the software Amos (Analysis of Moment Structure) version 18 and SPSS version 10. The results showed (1) the tourist product and the uniqueness of the environment positive and significant impact on tourist visits, (2) the tourist product and the uniqueness of the environment positive and significant impact on Length of Stay, (3) Determinants factors of length of stay tourists are tourist products and the uniqueness of the environment.
\end{abstract}

Keywords: Tourist products, environmental uniqueness, tourist visit and Length of Stay

\section{Introduction}

Indonesian tourism image basically has diverse tourism products spread all over the country. Biological diversity (biodiversity) flora and fauna provide an attraction for tourists in outdoor activities (ecotourism). Indonesia as a country mega biodiversity number two in the world, has been known to have natural resources, flora and fauna that has a very high potential to be used as one object and ecotourism attraction. The high biodiversity potential to appeal as well as its unique environment, natural make Indonesia has the potential to be developed system of natural tourism or ecotourism.

The low number of tourists who come to Indonesia becomes a big question considering the potential of tourism in Indonesia, especially from the aspect of tourism diversity better than Singapore. Empirical conditions which is the one of Problem Statement of this study. Suradnya study results (2005) states that an option will become a tourist attraction of tourists to visit depends on the attractiveness of tourism (tourism products) is concerned, the appeal factor environmental performance through the beauty of nature (natural beauty). Study confirms Suradnya (2005) that visits both foreign tourists and the archipelago into a tourist attraction in a country will eventually affect the structure of the national economy.

Other effects that can be caused by the development of a country's tourism sector is on employment, which through tourism and other related sectors will create new jobs. In line with the development of the tourism sector through increased tourist arrivals, which in turn have an impact on the increase of the overall workforce. Development of nature tourism (ecotourism) that rely on natural beauty, unique environment, cultural diversity will provide a positive impact to the economy through employment opportunities for actors in this tour of local communities. As said Fandeli, et al (2000), that Indonesia has a huge potential in the development of eco-tourism tropical forest area spread over the islands which is very promising for ecotourism and special tours. Some forest areas that can serve as a region-based tourism environment (ecotourism) is the area of the Nature Conservation (National Parks, Forest Parks, Nature Parks), and the Forest Preserve through the limited nature tourism activities, as well as production forest that serves as Wana Tourism.

The development of eco-tourism (ecotourism) so rapidly as one of the tourism industry with the potential to increase the revenue of the country, especially in the last decade. Nearly $10 \%$ of workers in the world, working in the tourism sector and not less than $11 \%$ of Gross Domestic Product (GDP) around the world comes from this sector. In Indonesia, ecotourism has donated income of Rp. 80 trillion by 2008 the number of foreign tourists of 6.5 million people. The receipts increased 33\% from 2007 ( $R p 60$ trillion). Hector Ceballos -

Lascuarin (1997) states that ecotourism as a logical part of sustainable development, requires a different approach to discipline and careful planning, both physically and management. 
The existence of an ecotourism area to be developed and can be visited by tourists foreign and domestic, can be seen from how many tourism products (variety of objects and tourist attractions) that can be enjoyed by tourists who visit these attractions. Another advantage that can be developed by ecotourism is the unique environment of the region, where it can be seen from how many species of flora and fauna which are endemic or rare category, so it takes a wise management of flora and fauna that scarcity is not more and more in order to maintain the uniqueness of an area.

Further description of the development of the tourism sector in the province of Central Kalimantan, with the availability of natural resources is quite big potential. Such as, revealed by Haryanto (2009) that the typical potential of natural resources and unique biodiversity in natural ecosystems, has a great chance to be sold on the world tourism market. Potential diversity of tourism products, particularly ecotourism, as mentioned previously, it is appropriate to put Central Kalimantan Province as one of the tourist destinations, both foreign tourists and domestic tourists. Tourist sights Tanjung Puting National Park Central in national tourism development strategy defined and included in the 33 major destinations nationwide (Ministry of Culture and Tourism, 2007).

Development of the tourism sector, both seen from the aspect of the number of tourist arrivals, as well as from the aspect of acceptance will describe how the tourism sector can be relied upon to encourage the economic growth of a region. Another thing that is important is the impact of all the direct and indirect involvement of the workforce in the various activities supporting tourism as a travel agent (travel agency), restaurant, tourist management, tour guides and so on. Based on data from BPS Central Kalimantan Province, showed that in 2007 the number of workers involved in the tourism system Central Kalimantan (restaurants, travel agents, tour manager, tour guide) was increased to as many as 262356 people in 2008, or an increase of $35.9 \%$. Relation to the length of stay of tourists in Tanjung Puting National Park in 2006-2009, are presented in Table 1

Table 1. Foreign Tourist Arrivals and length of the archipelago in Tanjung Puting National Park Year $2006-2009$

\begin{tabular}{|l|l|l|l|l|}
\hline \multirow{2}{*}{$\begin{array}{l}\text { N } \\
\text { o. }\end{array}$} & \multirow{2}{*}{ Year } & \multicolumn{2}{|l|}{ Tourist Visit (man/day) } & Average length of stay \\
\cline { 3 - 5 } & & Foreign & Domestic & Foreign \& Domestic Tourist \\
\hline 1. & 2006 & 3,947 & 2,273 & 3,11 \\
\hline 2. & 2007 & 3,385 & 2,687 & 3,04 \\
\hline 3. & 2008 & 4,561 & 2,377 & 3,47 \\
\hline 4. & 2009 & 4,493 & 1,949 & 3,22 \\
\hline \multicolumn{2}{|l|}{ Average } & 4,1 & 2,3 & 3,21 \\
\hline
\end{tabular}

Source: Annual Report 2010 Tanjung Puting National Park Agency

Table 1 showing that in the period 2006 to 2009 a length of stay tourists in Tanjung Puting National Park in the average was 3.21 days. This figure shows the level of long-stay relatively low when compared to other tourist destinations in Indonesia. Some with them, study of Ubjaan J (2007) states that the long-stay visits and travelers are influenced by factors tourist product, promotion, motivation trips. In understanding the results of this study further reinforce the tourism theory of the relationship between long-stay travelers with tourist products offered by a tourist attraction.

\section{Research Methods}

Based on the type of research, this research is explanatory research (explanatory research). In addition, this study included in the descriptive study. The study site is on the two National Park Tanjung Puting National Park as a tourist attraction which is included in the category of nature tourism (ecotourism) in the province of Central Kalimantan. The sampling technique used in this study is non probability sampling, namely Convenience sampling (sampling by convenience). In this study population included all tourists, both foreign tourists, domestic tourists who visit the sights in Tanjung Puting National Park in Central Kalimantan province. Population in terms of number of tourists in 2012 who visited the Tanjung Puting National Park is as much as 3,965 people. With reference to the statement Heir, et. al (1995) in Payangan (2005), the number of samples in this study were 150 respondents. In this study, the type of data used are primary and secondary data. Methods of data analysis using Path Analysis, to determine the causative relationship between variables exogenous and endogenous variables. Analysis tool used is reduced with the help of statistical application form and program AMOS ver. 18.0 and SPSS ver 10 .

The equation of the function is as follows: $Y_{1}=f\left(X_{1}, X_{2}\right) Y_{2}=f\left(X_{1}, X_{2}, Y_{1}\right)$ Reduce the calculation process form:

$\mathrm{Y}_{1}=\alpha_{0}+\alpha_{1} \mathrm{X}_{1}+\alpha_{2} \mathrm{X}_{2}+\varepsilon_{1}$

$Y_{2}=\beta_{0}+\beta_{1} X_{1}+\beta_{2} X_{2}+\beta_{3} Y_{1}+\varepsilon_{2}$

$Y_{2}=\beta_{0}+\beta_{1} X_{1}+\beta_{2} X_{2}+\beta_{3}\left(\alpha_{0}+\alpha_{1} X_{1}+\alpha_{2} X_{2}+\varepsilon_{1}\right)+\varepsilon_{2}$ 
$Y_{2}=\left(\beta_{0}+\alpha_{0} \beta_{3}\right)+\left(\beta_{1}+\alpha_{1} \beta_{3}\right) X_{1}+\left(\beta_{2}+\alpha_{2} \beta_{3}\right) X_{2}+\left(\varepsilon_{1} \beta_{3}+\varepsilon_{2}\right)$

where:

$\alpha_{1}=$ direct influence of the tourism product to tourist visits

$\alpha_{2}=$ direct influence of the environmental uniqueness to tourist visits

$\beta_{1}=$ direct influence of the tourism product to length of stay

$\beta_{2}=$ direct influence of the environmental uniqueness to length of stay

$\alpha_{1} \beta_{3}$ direct influence of the tourism product to length of stay through tourist visits

$\alpha_{2} \beta_{3}=$ direct influence of the environmental uniqueness to length of stay through tourist visits

\section{Fig. 1. Research Location Map}

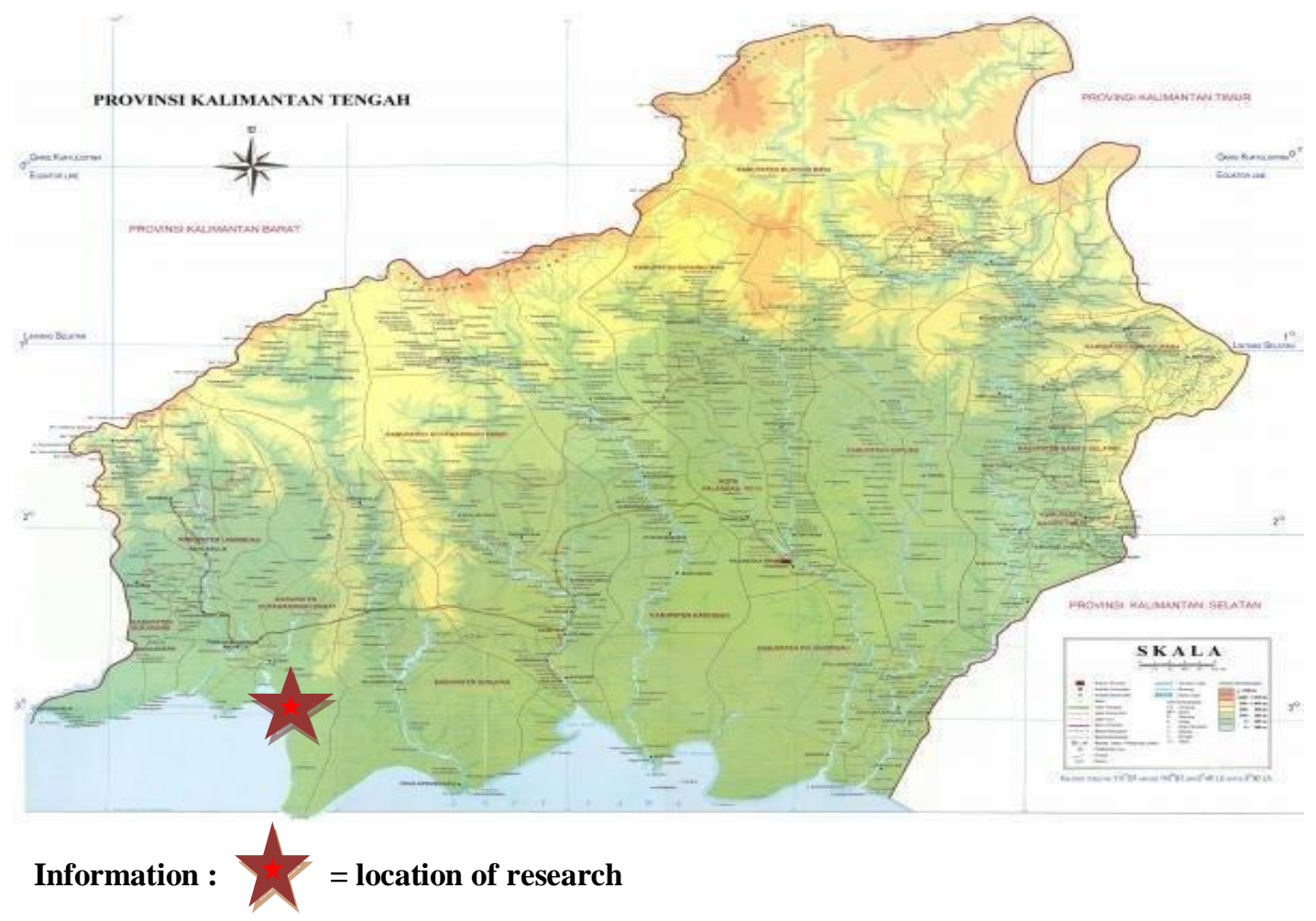

\section{Empirical Result}

To make it easier to analyze the functional relationship between variables then the value of the coefficients are arranged in the form of Table 1, as displayed in Table 1 below:

\section{The Influence of the Tourist Product to Tourist Visit}

Coefficients of variables influence the tourism product $\left(\mathrm{X}_{1}\right)$ to visit Tourism $\left(\mathrm{Y}_{1}\right)$ of 0.266 with a $t$ value of 3,189 at the significance level of 0.001 . The coefficient indicates that the variable tourist product $\left(\mathrm{X}_{1}\right)$ and a significant positive effect on visits Tourism $\left(\mathrm{Y}_{1}\right)$. This means that the increase in tourism product $\left(\mathrm{X}_{1}\right)$, will be followed by an increase in visits Tourism $\left(\mathrm{Y}_{1}\right)$, assuming other factors that affect the size of Visits Tourism $\left(\mathrm{Y}_{1}\right)$ is considered constant.

\section{The influence of the Environment Uniqueness to Tourist Visit}

The uniqueness of the environment variable effect coefficient $\left(\mathrm{X}_{2}\right)$ to visit Tourism $\left(\mathrm{Y}_{1}\right)$ of 0.342 with a $\mathrm{t}$ value of 6,341 at the significance level of 0.000 . The coefficient indicates that the uniqueness of the environment variable $\left(\mathrm{X}_{2}\right)$ and a significant positive effect on visits Tourism $\left(\mathrm{Y}_{1}\right)$. This means that the increase in environmental uniqueness $\left(\mathrm{X}_{2}\right)$, will be followed by an increase in visits Tourism $\left(\mathrm{Y}_{1}\right)$ assuming other factors that affect the size of Visits Tourism $\left(\mathrm{Y}_{1}\right)$ is considered constant.

\section{The Influence of the Tourist Product to Length Of Stay}

Coefficients of variables influence the tourism product $\left(\mathrm{X}_{1}\right)$ to Length Of Stay $\left(\mathrm{Y}_{2}\right)$ of 0.174 with a $\mathrm{t}$ value of 2.026 at a significance level of 0.035 . The coefficient indicates that the variable tourist product $\left(\mathrm{X}_{1}\right)$ and a significant positive effect on Length of Stay $\left(\mathrm{Y}_{2}\right)$. This means that the increase in tourism product $\left(\mathrm{X}_{1}\right)$, will be 
followed by an increase Length of Stay $\left(\mathrm{Y}_{2}\right)$; otherwise assuming other factors that affect the size Length of Stay $\left(\mathrm{Y}_{2}\right)$ is considered constant.

\section{The influence of the Environment Uniqueness to Length Of Stay}

The uniqueness of the environment variable effect coefficient $\left(\mathrm{X}_{2}\right)$ on Length Of Stay $\left(\mathrm{Y}_{2}\right)$ of 0.551 with a $t$ value of 2.019 at a significance level of 0.003 . The coefficient indicates that the uniqueness of the environment variable $\left(\mathrm{X}_{2}\right)$ and a significant positive effect on Length of Stay $\left(\mathrm{Y}_{2}\right)$. This means that the increase in environmental uniqueness $\left(\mathrm{X}_{2}\right)$, will be followed by an increase Length of Stay $\left(\mathrm{Y}_{2}\right)$ assuming other factors that affect the size Length of Stay $\left(\mathrm{Y}_{2}\right)$ is considered constant.

\section{The influence of the Tourist Visit to Length Of Stay}

Tourist Visits effect coefficient variable $\left(\mathrm{Y}_{1}\right)$ to Length of Stay $\left(\mathrm{Y}_{2}\right)$ of 0.265 with a t value of 2.205 at a significance level of 0.000 . The coefficient indicates that the variable visit Tourism $\left(\mathrm{Y}_{1}\right)$ and a significant positive effect on Length of Stay $\left(\mathrm{Y}_{2}\right)$. This means that the increase in visits Tourism $\left(\mathrm{Y}_{1}\right)$, will be followed by an increase Length of Stay $\left(\mathrm{Y}_{2}\right)$ assuming other factors that affect the size Length of Stay $\left(\mathrm{Y}_{2}\right)$ is considered constant

\section{Discussion}

\section{The Influence Tourist Products on Tourist Visit}

Variable of coefficients effect tourist products to tourist visit show that the tourism product variable positive and significant impact on visits Tourism. This indicates that the increase in tourism products (natural and man-made attractions, accessibility and tourist support facilities), will be followed by an increase in visits Tourism. According Yoeti (2002), that the tourism industry product basically consists of three interrelated components: (1) Accessibilities of the tourist destination, is all that can provide convenience to tourists to come visit on a tourist destination areas such as infrastructure, transportation, government regulations and operational procedures (2) Facilities of the tourist destination, is anything that serves to meet the needs of tourists during their stay in the area for a while in the visited tourist destination, such as accommodation, restaurant, transport in tourist destination areas, sports facilities and others (3) Tourist attractions, are all the appeal of why tourists interested in visiting the area sutau tourist destinations, such as attractions. Opinions Yoeti (2002) in line with the statement of Smith, (1989) and Choy, (1997) that the motivation of the tourists to visit tourist destination because of the availability of various facilities and infrastructure are inter-related, management and good organization, so it is not just the product The tour that provides comfort but management itself has to give comfort to every visitor of natural beauty, cultural attractions, local communities and the social attraction-made attractions. If Accessibilities of the tourist destination, Facilities of the tourist destination and Tourist attractions in good condition, well maintained and able to meet the expectations of travelers so that travelers satisfied with it, what they expect, it will increase tourist visits. This is in line with Kotler (2002) "Satisfaction is the level of one's feelings after comparing the performance (or outcome) compared with the perceived expectations." So, the level of satisfaction is a function of the difference between the perceived outcome expectations. Customers may experience any of the following levels of satisfaction: (1) when the product performance is worse than expected, the customer will be dissatisfied, (2) if the performance in line with expectations, the customer will be satisfied, (3) when performance exceeds expectations, the customer will feel very satisfied or happy.

\section{The influence of Environment Uniqueness on Tourist Visit}

Coefficients of variable influence the environment uniqueness to tourist visit shows that the uniqueness of the environment variable positive and significant impact on visits Tourism. This means that the improvement of environmental uniqueness, will be followed by an increase in visits Tourism. The uniqueness of the economic environment had an impact on tourist visits to the unique experience of the tourist environment, knowledge of the importance of nature conservation, educating visitors and add value to local residents around the area of ecotourism. This is in line with Kafyri, et. al (2012) which states that the unique environment of a tourist area will provide additional comfort and new knowledge for tourists visiting. Kafyri, et al (2012) emphasized that in order to maintain the authenticity and uniqueness of the environment of a tourist area needs to be done in nature conservation activities to maintain and develop the region. What is suggested by Kafyri et al (2012) became one of the development strategies Tanjung Puting national park as well as a conservation area and tourist areas. As conservation and rehabilitation of orangutans, Tanjung Puting National Park is an area that has a unique environment, so the main attraction to be visited by foreign tourists and domestic tourists.

\section{The Influence of The Tourist Product on Length Of Stay.}

Coefficients of variables influence tourism products to length of stay to indicate that travel product variable positive and significant effect on long-stay travelers. This means that the increase in tourism products, 
will be followed by an increase in long-stay travelers, assuming other factors that affect the size of the tourism product is considered constant. Accordingly, Kozak (2002) states that there are two fundamental things and the motivation for tourists to linger stay in the tourist attraction destination geography and country factors. Position of Tanjung Puting National Park in the national transport maps not include areas that are difficult to reach, because Soekarno Hatta airport as one of the entrances had been connected with the provincial capital Palangkaraya, Central Kalimantan. Also since the year 2013 the airline Kalstar open direct flights from Yogyakarta to Pangkalan Bun 3 times a week. So that through the accessibilities availability allows travelers to quickly get to the location of a tourist attraction. Opinions Kozak (2002) reaffirmed by Kim et al (2003), that there are three basic aspects as the driving factor tourists to visit the national park that is an object of natural resources support, information and convenience and accessibility and transportation facilities. So in this case the travelers who plan to stay for long in the tourist area of Tanjung Puting National Park due consideration comfort, good access and transport are relatively smooth.

\section{The influence of Environment Uniqueness on Length of Stay}

The uniqueness of the environment variable coefficients influence length of stay show that uniqueness of the environment variable positive and significant effect on long-stay travelers. This means that the improvement of the uniqueness of the environment, will be followed by an increase in long-stay travelers with the assumption that the other factors that affect the size of the uniqueness of the environment is considered constant. Ecotourism development by maintaining the level of environmental uniqueness of a region object will be able to guarantee the preservation of its natural tourist attractions that can be enjoyed by tourists while in tourist areas. Furthermore the duration of time spent by tourists to enjoy a tour package in the conservation area which has a unique ecosystem by tour. A at, al (2008) is influenced by economic variables such as a limited budget, income and prices. Attention to the characteristics of the respondents, especially tourists foreign, and economic factors seem cheaper prices provide greater opportunities for tourists to stay longer in Tanjung Puting National Park.

In line with what is proposed by the tours. A at, al (2008), Gokovali at. al (2007) confirmed that the long duration of stay of tourists affected by the hospitality, education, income, experience, familiarity and daily expenses. Empirically show that tourists visiting Tanjung Puting National Park gained a new knowledge, experience by enjoying the unique tourist attractions such as feeding the orangutan, river edge and artificial attractions such as dance and art woven rattan. Treat the unique attraction that makes tourist to stay longer in the area of the object.

\section{The Influence of Tourist Visit on Length Of Stay}

Effect of variable coefficient of tourist visits to the long stay of tourists showed that variables Tourism Visits positive and significant effect on long-stay travelers. This means that the increase in tourist visits, will be followed by an increase in long-stay travelers. Yoeti study results (1996) and Bagyono (2005), states that efforts to make the tourists to visit and stay at home longer, because of safety, comfort, attractive tourist potential, quality of service, accommodation and transport. Relation to the safety factor in the Tanjung Puting National Park area is relatively secure because the manager has put up signs that should and should not be done by tourists during the region are in the object. Another comfort for travelers in the region are accompanied by local guides who have a good understanding about the nature and capable of being a good interpreter. Furthermore, according to Fandeli (1994), Sutikno and Maryunani (2006), states that in order to make tourists stay longer in an area does not mean tourists are exploited throughout its economic capabilities, but the concept of service, as well as comfort and safety can be reached by the travelers, so travelers in turn will increase the duration of residence in the region. The guarantee of security and comfort, a good tourist preference to visit and stay in the tourist area of Tanjung Puting National Park.

This is in line with Marrioti (in Yoeti, 1990) the benefits and satisfaction is determined by two interrelated factors: first, the tourist resources contained everything a tourist destination that is an attraction for people to want to come for a visit to a place a tourist destination and second, that all the tourist service facilities and activities that can be used to do that provided by other companies procured commercially. The longer the stay of tourists will be able to increase the number of tourist visits.

\section{Conclusions}

Tourism product and the uniqueness of the environment positive and significant impact on tourist visits, thus increasing tourism products and increase the uniqueness of the environment will create an increase in tourist visits. This indicates that the access, convenience to amenities and unique tourist product environment will be followed by an increase in tourist visits and also the uniqueness of the environment continues to be preserved will increase tourist visits. Tourism product and the uniqueness of the environment positive and significant impact on length of stay of tourists so the increase of tourism products and unique environmental 
improvement will be followed by an increase in long-stay travelers. This indicates that if you want to increase the length of stay of tourists can also be done by increasing tourism products and preserve the uniqueness of the existing environment.

\section{References}

[1]. Andriani Kafyri, at.al. 2012. Determinants of visitor Pro-Environmental Intentions on Two Small Greek Island: Is Ecotourism Possible at Coastal Protected Areas?. Environmental Management (2012) 50:64-76.

[2]. Artal Tur, at. Al. 2008. The Length of Stay Determinants for sun-and-sand Tourism : An Application for the Region of Murcia. Journal Economic Literature. C12, R11, R58.

[3]. Bagyono,. 2005. Pariwisata dan Perhotelan. Edisi Juni. 2007. Bandung.

[4]. Balai Taman Nasional Tanjung Puting. 2010. Laporan Tahunan.

[5]. Buckley. R, 2009. Evaluating the net effects of ecotourism on the environment: a framework, first assessment and future research. Journal of Sustainable Tourism Vol. 17, No. 6, November 2009, 643-672.

[6]. Dinas Kebudayaan dan Pariwisata Kalimantan Tengah, 2010. Laporan Tahunan.

[7]. Fandeli, D. 1994. Defenisi Ekowisata. Paper

[8]. Fandeli, Chafis \& Mukhlison, 2000. Perusahaan Ekowisata. Fakultas Kehutanan UGM Yogyakarta.

[9]. Hair, J.F., et al. (1995). Multivariate Data Analysis With Reading, Ed.4. New. Jersey: Prentice Hall International, Inc

[10]. Gokovali, U. et. Al. 2007. Determinants of Length of Stay : A Practical use of Survival Analysis. Journal tourism Management. Volume 28, Issue 3. Pages 736-746.

[11]. Kementerian Kebudayaan dan Pariwisata, Laporan Tahunan. 2007

[12]. Lascuarin, H, C., 1997 . Ekotourism Sebagai Suatu Gejala Menyebar ke Seluruh Dunia. Ecotourism Society, North Bennington Vermont

[13]. Metin Kozak. 2002. Comparative Analysis of tourist Motivations by Nationality and Destinations. Tourism Management 23 (2003) 221-232

[14]. Payangan, O.R., 2005. Analisis Faktor-faktor Yang Mempengaruhi Kinerja Pemasaran Pariwisata di Sulawesi Selatan. Disertasi. PPs Unhas Makassar (Tidak dipublikasikan).

[15]. Samuel Seongseop Kim, at.al. 2003. The Influence of Push and Pull Factors at Korean National Parks. Tourism Management 24 (2003) 169-180

[16]. Suradnya, I Made, 2005. Analisis Faktor-Faktor Daya Tarik Wisata Bali Dan Implikasinya Terhadap Perencanaan Pariwisata Daerah Bali. Sekolah Tinggi Pariwisata Bali.

[17]. Yacob, M.R, 2011. Tourists Perception and Opinion towards Ecotourism Development and Management in Redang Island Marine Parks, Malaysia. Journal International Business Research. Vol. 4, No. 1; January 2011

[18]. Yoeti, Oka A., 2002, Pengantar Ilmu Pariwisata, Aksara, Bandung

\section{Appendix 1}

\section{Influences between variables in the form of path}

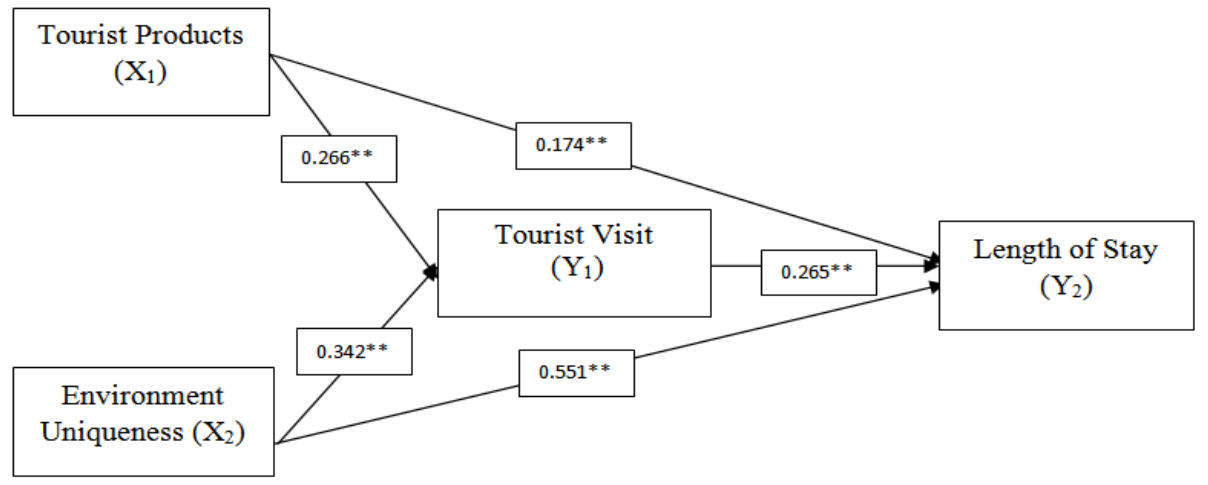

\begin{tabular}{|l|l|l|l|l|l|}
\hline $\begin{array}{l}\text { Independent } \\
\text { Variables }\end{array}$ & \multicolumn{2}{|l|}{ Dependent Variables } & Estimation & T Value & Prob. \\
\hline $\begin{array}{l}\text { Tourist Products } \\
\left(\mathrm{X}_{\mathbf{1}}\right)\end{array}$ & 1 & Tourist Visit $\left(\mathrm{Y}_{\mathbf{1}}\right)$ & 0,266 & 3,189 & 0,001 \\
\cline { 2 - 7 } & 2 & Length of Stay $\left(\mathrm{Y}_{\mathbf{2}}\right)$ & 0,174 & 2,026 & 0,035 \\
\hline $\begin{array}{l}\text { Environment } \\
\text { Uniqueness }\left(\mathrm{X}_{\mathbf{2}}\right)\end{array}$ & 1 & Tourist Visit $\left(\mathrm{Y}_{\mathbf{1}}\right)$ & 0,342 & 6,341 & 0,000 \\
\cline { 2 - 7 } & 2 & Length of Stay $\left(\mathrm{Y}_{\mathbf{2}}\right)$ & 0,551 & 2,019 & 0,003 \\
\hline Tourist Visit $\left(\mathrm{Y}_{\mathbf{1}}\right)$ & 1 & Length of Stay $\left(\mathrm{Y}_{\mathbf{2}}\right)$ & 0,265 & 2,205 & 0,000 \\
\hline
\end{tabular}

